6. Vermeiren S. et al. Frailty and the Prediction of Negative Health Outcomes: A Meta-Analysis. Journal of the American Medical Directors Association. 2016. 17(12). P. 1163-1163. DOI: 10.1016/j.jamda.2016.09.010.

DOI https://doi.org/10.30525/978-9934-26-038-4-14

\title{
СЬОГОДЕННЯ ПРОБЛЕМАТИКИ ГОСТРОГО ХОЛЕЦИСТИТУ, УСКЛАДНЕНОГО ПЕРИТОНІТОМ
}

\author{
Запорожченко Б. С. \\ доктор медичних наук, \\ професор кафедри хірургї № 2 \\ Одеський національний медичний університет
}

Кравець К. В.

аспірант кафедри хірургї̈ № 2

Одеський національний медичний університет

Бородаєв. I. Є.

кандидат медичних наук,

дочент кафедри хірургї № 2

Одеський національний медичний університет

Качанов В. М.

кандидат медичних наук,

доиент кафедри хірургї̈ № 2

Одеський національний медичний університет

\section{Зубков О. Б.}

доктор медичних наук, професор кафедри хірургї̈ № 2

Одеський національний медичний університет м. Одеса, Украӥна

Вступ. Друге місце серед хірургічних захворювань в Україні займає гострий холецистит (ГХ). Незважаючи на помітне удосконалення технологій, наукові надбання, кількість медикаментів та поліпшення результатів лікування, летальність після екстрених операцій (9,4-37\%) 
3 приводу ГХ ускладненого перитонітом залишається в кілька разів вище, ніж при планових оперативних втручаннях. [3]

Відзначається збільшення числа хворих похилого та старечого віку, які складають групи ризику, з причини важкого супутню патології за наявності деструктивних форм ГХ з ознаками перитоніту $[1,5]$. У цієї категорії хворих, показник летальності від ГХ досягає таких значень, як $27 \%[1 ; 3]$.

До теперішнього часу найбільш суперечливими питаннями в лікуванні ГХ є виважена постановка діагнозу та строки виконання хірургічного втручання з чітким визначенням виду операції.

Мета. Удосконалення хірургічної тактики та оцінка результатів лікування ГХ ускладненого перитонітом у хворих різних вікових груп.

Матеріали та методи. Проведено аналіз лікування 115 хворих у віці від 18 до 82 років з деструктивними формами ГХ з 2016 по 2021 р. Тривалість захворювання тривала від 5 годин до 7 і більше діб. $30(25,6 \%)$ хворих були госпіталізовані в строки до 6 годин від початку захворювання. У $52(45,8 \%)$ хворих давність захворювання становила 6-24 години, а $33(28,6 \%)$ хворих потрапили в хірургічне відділення після 24 годин 3 моменту розвитку ГХ.

Деструктивні форми ГХ відзначалися у $71(61,6 \%)$ хворих. Серед хворих 3 деструктивним холециститом дифузний перитоніт був виявлений у 20 (27,6\%) хворих, місцевий перитоніт і перівезікальний інфільтрат у $22(30,5 \%)$, а у $9(12,3 \%)$ хворих гангренозно-перфоративний холецистит з перівезікальним абсцесом.

У 16 (13,8\%) хворих ГХ був ускладнений механічною жовтяницею, яку планували усунути з використанням ендоскопічних інструментальних методів в самому початку лікування.

$113(98,5 \%)$ хворих прооперовані в різні строки від часу госпіталізації у хірургічне відділення. 3 них 43 (37,5\%) прооперовані в екстреному порядку, 41 (36,5\%) - в терміновому порядку, а 29 (26\%) - в відстроченому періоді

Основним видом операції було радикальне хірургічне втручання лапароскопічна холецистектомія (ЛХЕ). Проте, у хворих з підвищеним операційним ризиком, і з протипоказаннями до застосування карбоксіперітоніума використовували ліфтінгові системи [5,7], 3 метою зменшення негативного впливу карбоксіперітоніума.

У відстроченому періоді при використанні ЛХЕ у 3 (2,5\%) хворих виконувалася в умовах вираженого рубцово-спайкового процесу, що вимагало зміни ходу операції і виконання TXE. 
Вибір лікувальної тактики визначався патоморфологічною формою ГХ, наявністю його ускладнень і ступенем операційно-анестезіологічного ризику, з урахуванням віку хворого, термінів захворювання [3; 5].

Термінові операції в так звані «золоті 72 години», 3 моменту надходження хворих виконували при відсутності ефекту від консервативної терапії і збереження симптомів інтоксикації і місцевих перитонеальних явищ у 42 (36,5\%) хворих. При відсутності перитонеальної симптоматики і ознак інтоксикації продовжували консервативну терапію у хворих з важкою супутньою патологією.

У 8 (7\%) цих пацієнтів виконували ЛХЕ із застосуванням ліфтингових систем, при яких виключається негативний вплив напруженого пневмоперитонеуму на систему дихання і кровообігу.

Виконання лапароскопічної холецистектомії не повинно бути виконано «будь-що-буде».

Результати та їх обговорення. $100(86,5 \%)$ хворих оперовані із застосуванням лапароскопічних технологій (табл. 2).

При лапароскопічних втручаннях виконували інтраопераційну холангіографію у 11 (9,3\%) хворих. В даний час з'явилася можливість виконання флуоресцентної холангиографії.

Основними видами ускладнень, у 2 хворих, був запальний інфільтрат черевної порожнини та, у 1 хворого, підпечінкового простору, які не вимагали повторних операцій. Помер 2 (1,73\%) хворих від прогресування важкої супутньої патології, на тлі інтоксикації і явищ перитоніту. У 10 (8,5\%) хворих були виконані «відкриті» операції.

Цим хворим віконували ХЕ, санацію та дренування черевної порожнини одним або кількома дренажами. Ускладнення розвинулися у 1 $(11,76 \%)$ хворого.

Висновки. 1. ЛХЕ $є$ ефективною у ранні терміни від початку розвитку ГХ. Використання ліфтингових систем при ЛХЕ э доцільним у хворих похилого та старечого віку. У випадках ГХ, з помірним періпузирним процесом, і при гангренозному холециститі краще обирати ЛХЕ. Конверсія лапароскопії абсолютно виправдана в вертикальний трансректальний мінілапаротомний доступ.

2. При гострому деструктивному холециститі, ускладненому перівезікальним абсцесом, а також при всіх формах ГХ, ускладненого механічною жовтяницею, яку не вдалося вирішити ендоскопічно, в передопераційному періоді, найбільш раціональним є традиційне хірургічне втручання. 


\section{Література:}

1. Ceresoli M., Coccolini F., Montori G., Catena F., Sartelli M., Ansaloni L. Laparoscopic lavage versus resection in perforated diverticulitis with purulent peritonitis: a meta-analysis of randomized controlled trials. World J. Emerg Surg. 2016;11:42.

2. Бондарев Р.В., Иванцок В.М., Сопко А.И., Селиванова О.В., Селиванов С.С. Выбор метода санации брюшной полости при лапароскопической холецистэктомии у больных с острым деструктивным холециститом, осложнённым гнойным перитонитом. Хірургія Украӥни. 2016. № 4 (60). C. 30-33.

3. Мишалов В.Г., Иванцок В.М., Бондарев Р.В., Особенность профилактики послеоперационных гнойно-воспалительных осложнений при лапароскопической холецистэктомии деструктивного холецистита в старшей возрастной группе. XXIII з'їзд хірургів Украӥни (21-23 жовтня 2015 р., м. Київ): тези доп. Клінічна хірургія. 2015. C. $139-140$.

4. Zafar S.N., Obirieze A., Adesibikan B. et al. Optimal time for early laparoscopic cholecystectomy for acute cholecystitis. JAMA Surg. 2015. Vol. 150. № 2. P. 129-136.

5. Zaporozhchenko B.S., Kravets K.V., Kachanov V.N., Hasan Y., Gomonyuk I.V. Choice of tactics of surgical treatment of acute cholecystitis and its complications. Arta Medica. 2018. № 3 (68).

6. Б.М. Даценко, Т.И. Тамм, А.П. Захарчук, А.Я. Бардюк, И.А. Петленко, С.Б. Кутепов. Степень тяжести острого холецистита как основа выбора характера операции на принципах его активного хирургического лечения. Клінічна хірургія. 2018.

7. Ansaloni L., Pisano M., Coccolini F. et al. 2016 WSES guidelines on acute calculous cholecystitis. World J. Enmerg Surg. 2016. Vol. 4, № 1. P. 52. 